\title{
Sisterhood Really Counts: From Sexual Ambiguity to Androgyny
}

\author{
CHEN Hai-hui \\ Guangdong University of Foreign Studies, Guangzhou, China
}

\begin{abstract}
The leading character, Alexandra Bergson, in Willa Cather’s $O$, Pioneer! has aroused much discussion concerning her sexual orientation. By looking at how this character grows from a woman suffering from sexual ambiguity to one who achieves an composite of masculinity and femininity, this essay means to prove that although the writer's lesbianism influences her characterization to a certain degree, by endowing her characters with androgyny, Cather always attempts to create a group of characters who are striving for human beings wholeness.
\end{abstract}

Keywords: sexual ambiguity, sisterhood, androgyny, wholeness

\section{Introduction}

\section{Brief Introduction of Willa Cather and Her Works}

Willa Cather (1873-1947) is a very important female writer in the early 20th century American literature. She is especially noted for her novels about immigrants struggling to make a living in the Midwest from the late 1800s to the early 1900s. Her most popular novels include O Pioneer!, My Antonia and The Song of the Lark, in which she shows her deep affection for the land and her distaste for the materialism and conformism in modern life. She also created female characters with strength, courage and determination, having the capacity to face all obstacles in their lives. Since Cather's own gender identity was ascertained (she was a lesbian attracted only by woman), many critics focus on her lesbianism and contend that her characters, especially "her female characters reflect her own sexual orientation because of their characteristics which had previously been attributed only to man” (Geber, 1975, p. 223). While other critics challenge this view and assert that although Cather put many real people and experiences into her fictions, as a lesbian, "she did not openly refer to same-sex relationships and explore same-sex intimacies in her works. Rather she transformed her emotional life and experiences into acceptable, heterosexual forms and disguises" (Lindemann, 1970, p. 676). This essay, focusing on the female protagonist Alexandra Bergson in Willa Cather's O, Pioneer!, tries to find an answer to the above controversial issue. By looking at how this character grows from a woman suffering from sexual ambiguity to one who achieves an composite of masculinity and femininity, this essay means to prove that although the writer's lesbianism influences her characterization to a certain degree, but by endowing her characters with androgyny, Cather always attempts to create a group of characters who are striving for human beings wholeness.

\section{Introduction of Androgyny and Cather's Quest for Androgyny}

Derived from Greek and rooted in Greek mythology, the idea "androgyny” can be found in many fields.

CHEN Hai-hui, Master of English Language and Literature, Lecturer, Guangdong University of Foreign Studies. 
Take philosophy as an example, the concept of androgyny can be traced back to Plato's Symposium. "Plato said that the original human being was a hermaphrodite. The original person was formed with two halves, one male and one female. Then these got separated. That's why everybody's always searching for his half " (Hargreaves, 2005, p. 1). Moreover, androgyny is embodied in psychology as well. To put it simply, "Psychological androgyny means the blending of positive masculine and feminine characteristics within a given person" (Cook, 1985, p. 2). As a literary concept, it is put forward by Virginia Woolf and becomes a very important concept for her feminist thought.

Affected and inspired by some philosophers and writers, Woolf seems to have found a way to solve the long-lasting issue existing between man and woman, the two halves of human being. To be androgynous is to achieve the mixture of both masculine and feminine qualities not just physically but psychologically. In her essay A Room of One's Own, she contends that,

The normal and comfortable state of being is that when the two live in harmony together, spiritually co-operating. If one is a man, still the woman part of his brain must have effect; and a woman also must have intercourse with the man in her. Coleridge perhaps meant this when he said that a great mind is androgynous. It is when this fusion takes place that the mind is fully fertilized and uses all its faculties. (Woolf, 1988, p. 86)

The idea is first raised in her novel Orlando and embodied in her following works. For Woolf, it is fatal for anyone to write while thinking of their sex; it is also fatal to be a man or woman simple and pure. Writing with sexual self-awareness and bitterness may change the nature of the text and thus destroy the whole work, so she puts much emphasis on the transcendence of sex limitation and impersonality.

Androgyny has exerted enormous impact on many social fields and has great influence on literature. Some outstanding female writers have applied the concept of androgyny in their works. Willa Cather also belongs to this group. Though she never claimed, Cather, as a writer, together with her impressive characters, possesses the characteristics of androgyny. In the following part, the thesis will apply the theory of androgyny to analyze Cather's work $O$, Pioneer! and its protagonist Alexandra Bergson.

\section{Introduction of the Female Protagonist Alexandra Bergson and Her Ambiguous Identity}

O Pioneers! (1913) tells the story of Alexandra Bergson and her determination to save her immigrant family’s Nebraska farm. Clear-headed and fiercely independent, Alexandra's passionate faith in the prairie makes her a wealthy landowner. Different from traditional women, Alexandra is not content with the destiny predetermined by the society for her, which is bearing and catering to men. The author endows Alexandra with "the strength of will, intellect, power, independence, originality, self-control as well as intuition, passion, generosity, care for others and beauty" (CAO, 1995, p. 92). Being the oldest child, Alexandra takes on a lot of responsibilities to help her father support the family on this unfriendly land. Even as a young girl, she has learned that in order to survive, one has to face the problems instead of running away from them. After her father's death, Alexandra becomes the backbone of the family. On one hand, she has to handle domestic routines properly and efficiently and looks after her younger brothers. On the other hand, unlike most other frontier females, Alexandra does not confine herself to the household duties always allotted to women in the sexual division of labor. The more important part of her life is outside the house. She works in the fields, reads the papers, follows the markets, and learns by the mistakes of their neighbors. It is she who has her family's fate in hand. 
While in the first part of the novel, although being so successful in taming the wild land and fulfilling her duty, Alexandra seldom takes great pleasure in her achievement. On the country, her economical success hinders her from pursuing happiness. In order to keep the money and the land in their hands, her selfish brothers treat her as a tough woman wearing a "male mask" and deliberately turn a blind eye to her traits and needs as a woman; With the responsibilities and obligations imposed on her, Alexandra herself also consciously denies her feminine characteristics and undergoes intense suffering because of her ambiguous sexual identity.

\section{A Woman Suffering From Ambiguous Sexual Identity}

If a person suffers from ambiguous sexual identity, the feminine and masculine qualities combine together in his/her mind, but in an ambiguous state. The person can sense both sexes, but feels belong to neither (CAO, 1995, p. 78). He/she does something in order to disguise and reject his/her identity based on biological factors. In the first two parts of the novel, Alexandra shows great rejection of femininity.

\section{Cross-dressing}

Alexandra is portrayed as a woman with masculine physical traits. When she first comes on the scene, she is described as,

.... a tall, strong girl, and she walked rapidly and resolutely, as if she knew exactly where she was going and what she was going to do next. She wore a man's long ulster (not as if it were an affliction, but as if it were very comfortable and belonged to her; carried it like a young soldier), and a round plush cap, tied down with a thick veil. ${ }^{1}$ (Cather, 1989, p. 5)

The writer devotes a whole paragraph to depicting her image, emphasizing on the heroine's cross-dressing and her masculine-style appearance. Although physically, she possesses feminine beauty, she always tends to conceal it by wearing man's clothes and even annoyed when a man spontaneously shows admiration for her beauty. Clothes do not just keep people warm, instead they function as a means to show or disguise one's own identity. In her book Fantastic Women: Sex, Gender and Transvestism, Annie Woodhouse comments that,

...appearance is more than simply the physical, outward manifestation of gender. It both molds and is molded by, a person's own sense of identity... In short, appearance makes a statement about what a person is (or would like to be) and about the groups that person identify with. When women do wear masculine-style fashion, this can confer touches of masculine status. (1989, p. 9)

Alexandra's indifference to her feminine beauty and her refusal to be treated as an object of man's desire reveals her longing to become one member of the power male world at the sacrifice of her feminine beauty. Therefore, Alexandra's transvestism seems to be a subversion of female stereotypes and defiance of traditional female values, but in essence, it indicates her internalization of male values which in turn reveals her acceptance of inferiority of being female in a patriarchal society.

\section{Oppression of Female Desire}

Dreams, in Freud's view, are all forms of "wish fulfillment"-attempts by the unconscious to resolve a conflict of some sort, whether something recent or something from the recesses of the past (1997, p. 26). What a

\footnotetext{
${ }^{1}$ All the quotations from O, Pioneers! are quoted from Willa Cather (1989), O, Pioneers!, New York: Bantam Books. Further references are seen in the parentheses.
} 
person dreams will reflect his oppressed wills and desire. Throughout her girlhood she has often on Sunday mornings had the same dreams of being carried by a strong man across the fields.

\footnotetext{
...she used to have an illusion of being lifted up bodily and carried lightly by some one very strong. It was a man, certainly, who carried her, but he was like no man she knew; he was much larger and stronger and swifter, and he carried her as easily as if she were a sheaf of wheat... She could feel him approach, bend over her and lift her, and then she could feel herself being carried swiftly off across the fields. (Cather, 1989, p. 131)
}

This recurring fantasy indicates her natural sexual desire as a physically normal woman, but as she consciously inhibits her femininity, "after such a reverie she would rise hastily, angry with herself, and go down to the bath-house", and "prosecute her bath with vigor, finishing it by pouring buckets of cold well-water over her gleaming white body” (Cather, 1989, p. 131). She is ashamed of her spontaneous overflow of feelings and emotion in the dreams because of her habit of repressing of the feminine sexual consciousness, thus indicating her internalization of the patriarchal value which considers femininity to be inferior to masculinity.

\section{Rejection of Carl's Love}

Because of her ambiguous sexual identity and her full commitment to her land, Alexandra is very indifferent to Carl, her long-suffering admirer and subdues her crave for love consciously and unconsciously. They have known each other since they were young and Carl has been emotionally attached to Alexandra for many years, though he has never put it explicitly in words. When he is nineteen, Carl goes away to big cities for a better life. Sixteen years later, he comes back as a single man and finds Alexandra, a woman nearly forty, hasn't got married yet, Carl therefore takes the courage to express his love to Alexandra by saying that "you must see that you astonish me. You must feel when people admire you" (Cather, 1989, p. 69). Alexandra avoids giving a direct response to Carl by attributing people's, including Carl's, admiration for her to the fact that people are "more pleasant to do business with people who are clean and healthy-looking” (Cather, 1989, p. 69). Carl is embarrassed and disappointed by her answer and gives a "dry chuckle" (Cather, 1989, p. 69). Because she is too obtuse to take the hint, Carl, a very conservative man, goes away again in disappointment. Alexandra reaction is rooted in her idea of self-identity. For so many years, she has been expected to be rational, tough and determined to conquer all the difficulties like a man and gradually, she has internalized that expectation thrusted upon her and got accustomed to being treated as a man by others. Although she confesses that she feels so lonely all the time, even her dearest little brother Emil takes it for granted that “Alexandra's never been in love. She wouldn’t know how to go about it” (Cather, 1989, p. 80). Lacking in femininity is a vital flaw in her personality that leads to her tedious life but also paves the way for her change to an androgynous person.

Her consciousness of being an individual woman is awakened when she quarrels with her brothers Lou and Oscar. In order to keep the property to themselves, the selfish brothers are worried about the relationship between Alexandra and Carl. They assert that the property of a family belongs to the men of the family and accuse Alexandra of being hard on them. Alexandra outrageously answers back,

Hard on you? I never meant to be hard. Conditions were hard. Maybe I would never have been very soft, anyhow; but I certainly didn't choose to be the kind of girl I was. If you take even a vine and cut it back again and again, it grows hard, like a tree. (Cather, 1989, p. 88) 
This is the first time Alexandra bravely fights against the patriarchal oppression. Later, with more and more interactions with Marie, a passionate, vigorous and courageous woman, Alexandra achieves androgyny. The next part of the essay will elaborate how sisterhood helps Alexandra to obtain androgyny.

\section{Androgyny by Way of Sisterhood}

\section{Definition of "Sisterhood"}

The theme of "sisterhood" recurs frequently in many novels, especially those written by female writers. Toni Morrison's saying "The loneliest woman in the world is a woman without a close woman-friend” (1970, p. 89) illustrates the significance of "sisterly-love" for women. "Sisterhood" refers to the friendship between two women or among more women living together or forming groups for common support. Leung Lai-fong defines it as,

\footnotetext{
...the relationship between and among women represented as close in order to relieve tension, where the women are wanting companionship, freedom to speak openly, support in educating themselves, or advice; the women are there for each other without being judgmental. (1997, p. 142)
}

To put it simply, Leung stresses such characteristics of sisterhood as collectivity, companionship, free expression, support and equality. Women who have developed such intense friendship "understand, support and care for each other spiritually, emotionally and politically so that they can defend their rights, establish the female selfhood and even construct her-story” (Koppelman, 1991, p. 280). In the novel, Alexandra, inspired by her intimate friend Marie, begins to challenge the patriarchy and assert herself as an individual woman.

\section{Sisterhood to Defy Patriarchy}

Private talks as enlightenment and healing. Marie's insistent cheer and friendly effervescence make her an easy friend for her neighbor Alexandra. Both of them are caught in a trap of achieving successful romantic relationships. Marie, who is a beautiful, vibrant girl, for whom life exists to be experienced fully, is married to Frank Shabata. Frank was a dandy once, with a yellow cane and everything, but once married, he becomes something of a misanthrope. The only thing that makes him happy is making Marie sad. Marie's unhappiness is compounded by her inability to improve her situation, since she is a believing Catholic, precluding the possibility of divorce. Her love with Emil places her on the brink of infidelity to her husband and finally leads to her death; Alexandra's attachment to Carl is devoid of any romantic element; their friendship seems to serve more as a mutual pact against loneliness. They are in the same boat for their suffering while at the opposite ends of a spectrum at the same time: one is too romantic and the other is too rational and down to the earth, while Alexandra is strangely attracted to Marie for "in her, the uncontrollable girl, she can feel something unexplainable that she lacks but also craves for" (Cather, 1989, p. 90). For this reason, Alexandra constantly goes to Marie's home and has very intimate talks in which both of them relating their sadness and loneliness to each other so they get companies to confess to, to laugh and cry with. In this way, Cather helps us recognize the significance of sisterly love which has been ignored in the male writing; that is, sisterly love in the forms of talking, laughing and sharing serves to heal what women have suffered and then help them love their self.

Marie's death as an spiritual epiphany. The story comes to the climax when Marie and Emil are murdered by Frank in the orchard. When Alexandra comes to the scene, she is shocked by what she sees: 
There was something about those two lying in the grass, something in the way Marie had settled her cheek on Emil's shoulder, that told her everything. She wondered then how they could have helped loving each other; how she could have helped knowing that they must. Emil's cold, frowning face, the girl's content-Alexandra had felt awe of them, even in the first shock of her grief. (Cather, 1989, p. 148)

Only at this moment does Alexandra realize how much they love each other. Although Marie has complained to Alexandra about her hopeless, suffocating marriage; and Carl has reminded her of the subtle sentiment between Emil and Marie, Alexandra hasn't got an idea about how compelling their love will be until facing the death of the poor two. Though she remains uncertain as to whether Emil and Marie are to blame for their own deaths, from Marie's death, she gets a new message about a woman's struggle for true love and own identity, even at the cost of her own life. Falling a victim of the androcentric society, Marie is doomed to end tragically; while for her, death is also a kind of relief, which enables her to be with Emil forever. In the end, Marie achieves the fulfillment of her life by being together with Emil. In a sense, Marie transcends the patriarchal culture.

On a stormy October evening three months after the murders of Emil and Marie, Signa sends Ivar in search of Alexandra, who has vanished into the storm. Ivar finds her alone, in the rain, at Emil's grave. Her exposure to the storm induces exhaustion, and Alexandra must spend the next few days in bed, recovering; as a result, Alexandra undergoes a sort of catharsis. Again the vision that has perplexed and comforted her throughout her life recurs, that of a powerful, golden man, lifting her up and easing her weariness. She has time now to reflect, with a certain distance, on the tragedy that has befallen her family. At the end of the novel, she realizes the vital flaw in her character, deciding to reunite with Carl and emerges as a sound and whole person who has overcome her self-limitations and begins to see what the world is like through both man's and woman's eyes. The "sisterly-love" between Alexandra and Marie inspires her to seek after the sense of wholeness, the balanced state of androgyny.

\section{Conclusion}

This essay provides an analysis of Cather and her character Alexandra from the perspective of sisterhood and androgyny. It may not be enough to solve the controversies over the author and her works, but it allows us to approach the unconventional female characters in the novel from a new perspective. In her writings, males are no longer the unshakable dominators while woman try to break off the shackles of patriarchy. They are presented as completed human beings who embody both masculinity and femininity. Through her characterization, Cather demonstrates her effort to challenge the social prejudges against women and tries to build a new image of women who get rid of the confinement imposed by patriarchy.

\section{References}

CAO, J. H. (1995). The search for female identity-women characters in Willa Lather's fictional works. Beijing: PLA Press. Cather, W. (1989). O, pioneers!. New York: Bantam Books.

Cook, E. P. (1985). Psychological androgyny. Pergamon Press.

Freud, S. (1997). The interpretation of dreams (3rd ed.). (A. A. Brill, Trans.). Hertfordshire: Wordsworth Editions Ltd.

Gerber, P. L. (1975). Willa Cather. Boston: Twayne Publishers.

Hargreaves, T. (2005). Androgyny in modern literature. New York: Palgrave Macmillan.

Koppelman, S. (Ed.). (1991). Women's friendships: A collection of short stories. Norman: University of Oklahoma Press. 
Leung, L. F. (1989). In search of love and self: The image of young female intellectuals in Post-Mao women's fiction. In M. Duke (Ed.), Modern Chinese women writer: Critical appraisals (pp. 135-151). New York: M. E. Sharpe, Inc.

Lindemann, M. (1989). Willa Cather: Double lives. New York: Pantheon Book.

Morrison, T. (1970). The bluest eye. New York: Washington Square Press.

Woolf, V. (1998). A room of one's own. In S. Lawall (Ed.), The Norton anthology world masterpieces. New York: W. W. Norton \& Company, Inc.

Woodhouse, A. (1989). Fantastic women: Sex, gender and transvestism. Hampshire: Macmillan. 